Pedagogy and Psychology of Sport, Vol. 2 / No 1, 2016

Romanchuk A. P., Guziy O. V., Glushchenko M. N., p. 20-40

Received: 21.12.2015. Revised 25.12.2015. Accepted: 10.01.2016.

DOI:http://dx.doi.org/10.12775/PPS.2016.003

Original Text published (C) The Author (s) 2016.

Romanchuk A. P., Guziy O. V., Glushchenko M. N. Статевi особливості сенсомоторної функції осіб молодого віку з урахуванням моторної асиметрії $=$ Gender features of sensorimotor function in young people with motor asymmetry. Journal of Education, Health and Sport. 2016;6(1):38-63. eISSN 2391-8306. DOI http://dx.doi.org/10.5281/zenodo.44575 http://ojs.ukw.edu.pl/index.php/johs/article/view/44575

\title{
Gender features of sensorimotor function in young people with motor asymmetry
}

\section{Статеві особливості сенсомоторної функції осіб молодого віку з урахуванням моторної асиметрії}

\author{
${ }^{1}$ Romanchuk A. P., ${ }^{2}$ Guziy O. V., ${ }^{1}$ Glushchenko M. N. \\ ${ }^{1}$ Романчук О. П., ${ }^{2}$ Гузій О. В., ${ }^{1}$ Глущенко М. М.
}

\author{
${ }^{1}$ South Ukrainian National Pedagogical University n.a. K.D. Ushinsky \\ ${ }^{2}$ L’viv State University Physical Culture \\ ${ }^{\mathbf{1}}$ Південноукраїнський національний педагогічний університет ім. К.Д. Ушинського \\ ${ }^{2}$ Львівський державний університет фізичної культури
}

Keywords: gender, sensorimotor function

Ключові слова: стать, сенсомоторна функція

\begin{abstract}

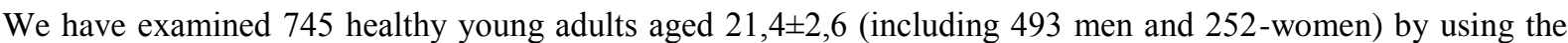
appliance «Computer movements measurer». Having investigated the sexual features of sensor-motor function taking into account the motor asymmetry we have found that the most likely $(p<0,05)$ differences between the central (switch of central units), subcortical (movement cycle durability) and medullary (reaction time to light) mechanisms of movements appear in left-handed women. The significant results show that there is the polynomial relationship between the left and right hand accuracy measures by taking into account the motor asymmetry in both men and women.
\end{abstract}

\section{Анотація}

3 використанням приладу «Комп'ютерний вимірювач рухів» були обстежені 745 практично здорових

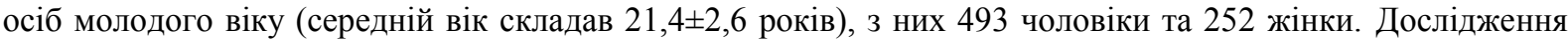
статевих особливостей сенсомоторної функції з урахуванням моторної асиметрії дозволило встановити, що найбільш вірогідними $(\mathrm{p}<0,05)$ визначались відмінності у виражено ліворуких жінок, які стосувались центральних (за показником ПЦУ), підкоркових (за показником ТЦР) та медулярних(за показником ЧРС) механізмів організації рухів. Серед результатів дослідження вагомими виявилися дані, які свідчать про поліноміальну залежність між показниками влучності правою та лівою рукою з урахуванням моторної асиметрії, як у чоловіків, так і у жінок. 


\section{Актуальність}

Визначення сенсомоторної функції $€$ перспективним напрямком дослідження психофізіологічних особливостей організму. Багато вітчизняних та зарубіжних вчених використовують діагностику сенсомоторної функції для вивчення когнітивних процесів [33, 6, 15], оцінки функціонального стану ЦНС [32, 34, 36], сенсорної чутливості [22, 31], розвитку моторики [23, 36, 21], психофізіологічних i нейрофізіологічних параметрів функціонування головного мозку [9, 14, 17]. Завдяки своїй простоті і інформативності, сенсомоторні тести все частіше використовуються в діагностиці порушень психофізичного розвитку дітей $[8,19,22,24,26,28,30,35]$, при захворюваннях і травмах ЦНС [13, 32].

Дослідження функціональних можливостей центральної нервової системи з урахуванням швидкості і влучності виконання сенсомоторних тестів дозволяє виявити функціональні зрушення в умовах мінливої аферентації [12].

Загальною структурною схемою організації сенсомоторних процесів є рефлекторне кільце [2]. Сенсорна інформація, яка прямує від аналізаторів, здійснює запуск, регуляцію і контроль рухів. Крім того, в

процесі безпосереднього виконання рухів вони коригуються 3 урахуванням нової сенсорної інформації. Координація сенсорних і моторних компонентів рухового акту найважливіша умова функціонування сенсорних систем [4].

При цьому відбувається складна взаємодія висхідного потоку збуджень 3 керуючими імпульсами із мовленнєвих відділів кори головного мозку, які можуть вибірково посилювати або пригноблювати роботу окремих нервових структур, приймаючи на себе роль вищого акцептора результату дії і визначаючи складну динаміку психофізіологічного процесу як в його аферентній і центральній частині, так і в ділянці низхідних ефекторних систем [18].

Сенсомоторні реакції в першу чергу характеризуються таким психофізіологічним поняттям, як «час реакції», під яким звично розуміють інтервал часу між появою сигналу і реакцією відповіді.

Це комплексне утворення, яке визначається сумарною сукупністю таких елементів $[12,23,31]:$

- швидкість збудження рецептора i посилання імпульсу в відповідний центр чуттєвості;

- швидкість переробки сигналу в ЦНС;

- швидкість прийняття рішення про реагування на сигнал;

• швидкість передачі сигналу до початку дій по еферентним волокнам; 
- швидкість розвитку збудження в м'язі і подолання інерції тіла або його окремої ланки.

В даний час все більш очевидною $є$ наявність функціональної міжпівкульної асиметрії головного мозку, яка проявляється взаємодіями півкуль з вищими центрами вегетативної регуляції [16, 20]. Як приклад,

дані про асиметрію активності і енергообміну вискової кори [11]; дані про протилежні зміни вегетативних функцій, викликаних стимуляцією симетричних утворень інсулярної кори [7]; дані про функціональне домінування правої півкулі при активації симпатичного відділу ВНС та функціональне домінування лівої півкулі при активації парасимпатичного відділу ВНС, яке спостерігається в стані спокійного пильнування $[5,10,25]$. Важливе значення надається дослідженню статевих особливостей міжпівкульної асиметрії $[1,16]$.

3 огляду на відомі методи визначення властивостей ЦНС, всі вони базуються на активних діях на сферу умовно-рефлекторної діяльності або через зміну рівня мотивації, або через штучну зміну збудливості ЦНС при введенні медичних препаратів, або шляхом зміни сили використовуваних подразників, порядку їх дотримання, зміни ïx просторово-часових характеристик, або шляхом оцінки швидкості реагування на гальмівні і збуджуючі сигнали [12].

Відтворення усіх перерахованих способів в практиці експресдіагностики основних властивостей нервової системи людини або повністю виключено, або надзвичайно трудомістко, тому упродовж багатьох років ведуться пошуки досить простих, але об'єктивних тестів визначення основних властивостей ЦНС - сили і функціональної рухливості нервових процесів, балансу збудливо-гальмівних процесів $[2]$.

\section{Методи}

Для об’єктивної кількісної оцінки стану мозкових структур, які виконують програмування, ініціацію, реалізацію і сенсорний контроль рухової активності осіб молодого віку був використаний прилад КВР-3 (рис.1), розроблений під керівництвом В. В. Пивоварова [27]. 


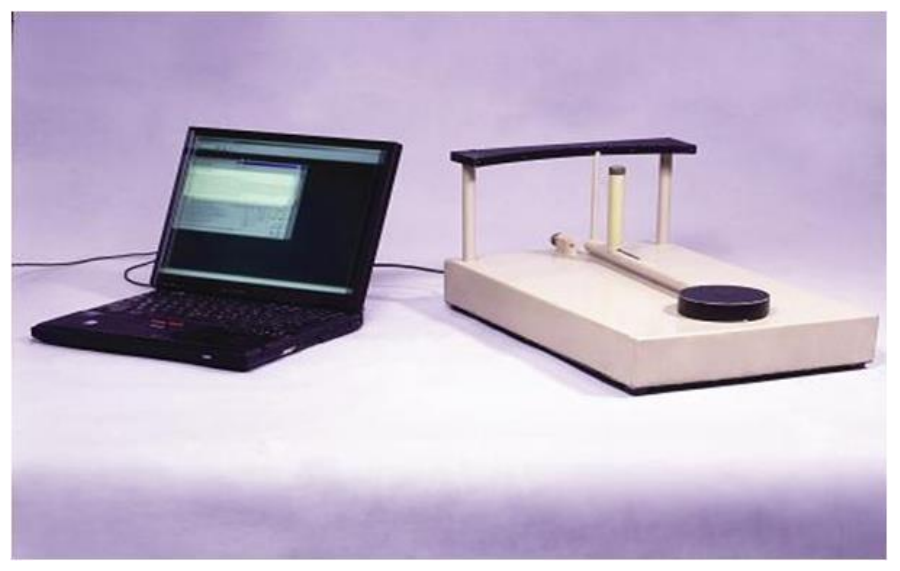

Рис. 1. Загальний вигляд приладу КВР-3.

За його допомогою за результатами виконання трьох простих рухових тестів (рис. 2-4), які виконуються правою та лівою рукою, визначались 25 цифрових параметрів рухів: тривалість циклу руху (ТЦР, с) перемикання центральних установок (ПЦУ, с), час реалізації флексії і екстензії (ЧРФ і ЧРЕ, с), короткотермінова рухова пам'ять (КРП, c), час реакції на звуковий подразник (ЧРЗ, с), час реакції на світловий подразник (ЧРС, c), помилка корекції флексорів і екстензорів (ПКФ и ПКЕ), плавність рухів (ПР, \%), баланс екстензорів і флексорів при візуальному контролі і без нього (БЕФвіз і БЕФ), а також коефіцієнт моторної асиметрії управління рухами.

Методика першого тесту полягає у виконанні поворотів важеля в горизонтальній площині вправо-вліво в діапазоні, позначеному світловими маркерами. Випробовуваному пропонують рухати важіль між двома світлодіодами, які світяться, 3 максимально можливою швидкістю і з максимально можливою точністю. У цьому ж тесті перед обстежуваним ставиться завдання екстреної перебудови рухової установки, коли змінюється пара світлодіодів, що світяться. Умови першого тесту найбільш оптимальні для реалізації зорово контрольованих рухів. Перша фаза руху (балістична) реалізується без участі систем зворотного зв'язку за рахунок включення механізмів збудження (250-300 мс). Друга фаза - коригування руху і точна підгонка курсору до мети - здійснюється з урахуванням інформації, що поступає по каналах зворотного зв'язку (кінестетичному і зоровому) за рахунок гальмівних механізмів.

При цьому відбувається запис кінематограми (рис.1). По кінематограмі розраховуються параметри: ТЦР, ПЦУ, ЧРЕ, ЧРФ, ПКФ, ПКЕ та ПР. 


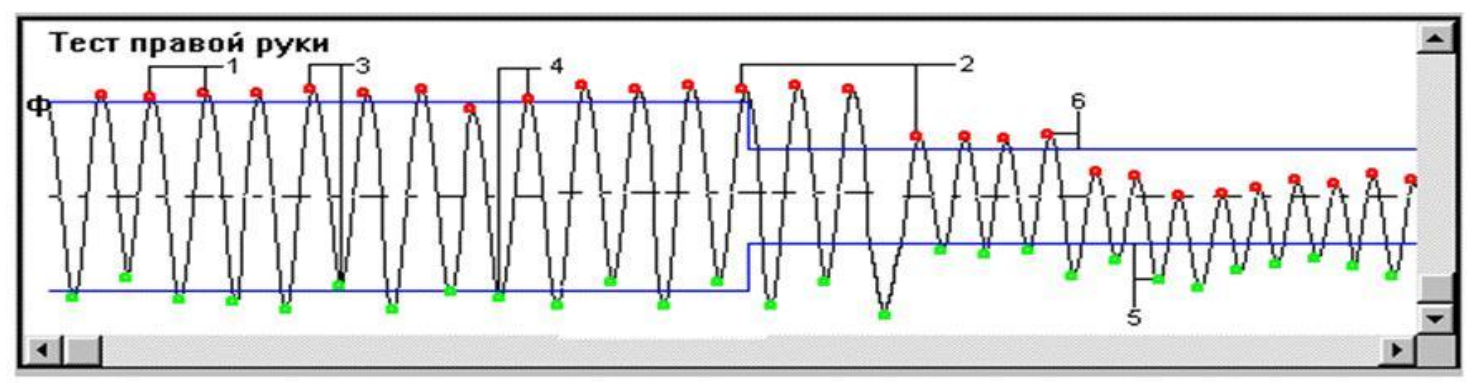

Рис. 2. Кінематограма 1 тесту, де: 1 - ТЦР, 2 - ПЦУ, 3 - ЧРФ, 4 ЧРЕ, 5 - ПКФ, 6 - ПКЕ.

Структура рухів, що реалізовуються при основних процедурах тестування на КВР, носить ритмічний характер, у зв'язку з чим плавність руху (ПР) оцінюється на основі співвідношення гармонік спектру Фур'є, як доля основної гармоніки у відсотках. Чим більшою є доля основної частоти, тим вища плавність руху. Низька плавність руху свідчить про неврівноваженість збудливо-гальмівних процесів (може спостерігатися, наприклад, при неврозах, недорозвиненні лобових доль, початковій стадії ДЦП). Нерівномірність руху однієї руки може бути ознакою порушень в протилежній півкулі мозку. В той же час показник перемикання центральних установок (ПЦУ) тісно пов'язаний із функцією уваги, за яку відповідальна префронтальна зона кори головного мозку. Крім того цей показник свідчить про здатність індивідуума модифікувати просторово-часові характеристики, вже здійснюваної дії при раптовій зміні сигналів із зовнішнього середовища або рухової адаптації індивідуума до нових сигналів.

Другий тест призначений для оцінки рухової діяльності при знятті зорового контролю. Протягом першої частини цього тесту випробуваний виконує рухи в таких же умовах, що й у першому тесті, а потім, після подачі сигналу, він продовжує реалізацію тесту із закритими очима.

Успішне виконання даного тесту вимагає від випробуваного реалізації короткострокової рухової пам'яті або переходу на пропріоцептивний контур керування рухом. У тесті на виконання руху заданої амплітуди із закритими очима оцінюється моторна пам'ять за величиною зміщень граничних положень важеля при роботі iз закритими очима в порівнянні з цим же показником за останніх 10 с. режиму роботи 3 розплющеними очима. Негативні значення цієї величини вказують на більше зміщення при роботі флексорів, позитивні - на більше зрушення при екстензорній фазі руху (Рис. 3). 


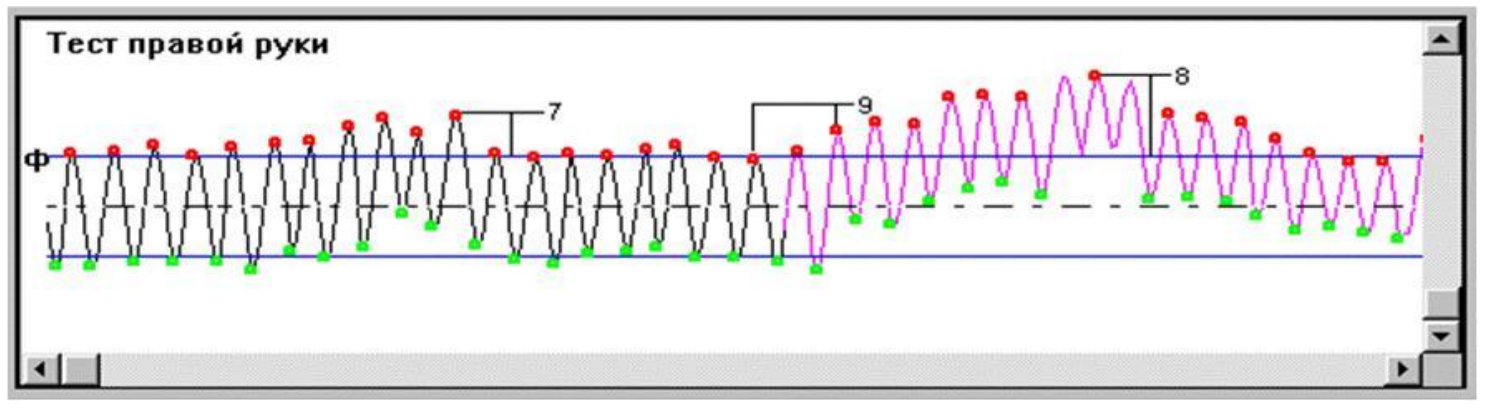

Рис. 3. Кінематограма 2 тесту, де: 7 - БЕФвіз, 8 - БЕФ, 9 - КРП .

Третій тест розроблений для виміру латентного періоду простої рухової реакції на світловий (спалах світлодіода на панелі) і звуковий (клацання динаміка) подразники. У відповідь на стимул випробовуваний повинен зробити максимально швидке зміщення важеля $з$ довільною амплітудою і повернути курсор в початкове положення. Особливість цього виміру полягає в тому, що реакція випробовуваного організовується не у вигляді простого замикання кнопки, а у вигляді зрушення важеля 3 позначеної мітки.

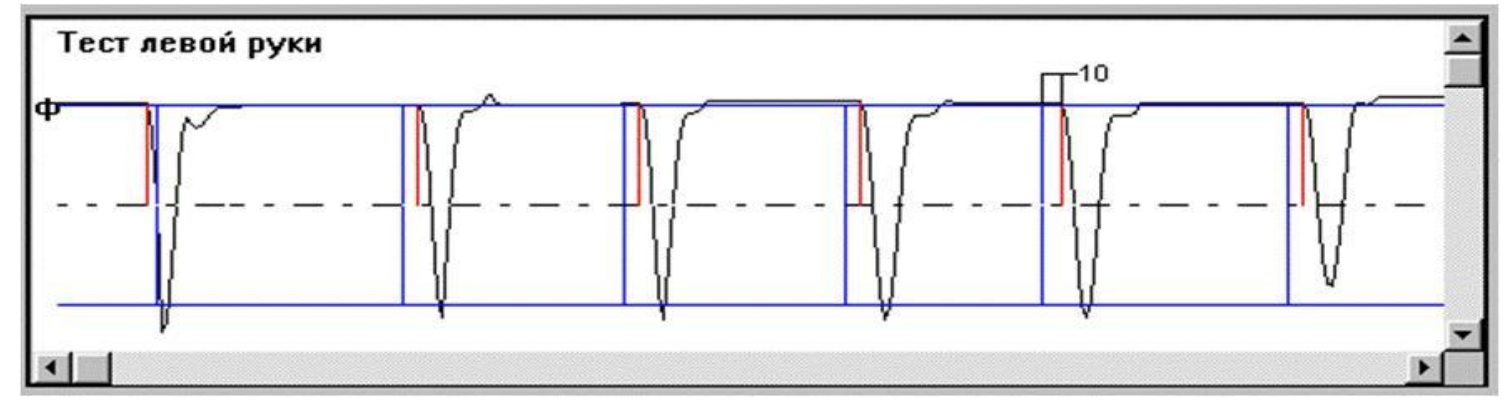

Рис. 4. Кінематограма 3 тесту, де: 10 - ЧРС (ЧРЗ).

3 урахуванням даних тестування розраховується коефіцієнт моторної асиметрії (КА). КА більший 10\% свідчить про праворукість, а менше -10\% - про ліворукість, проміжні значення оцінюються як дворукість

(амбідекстри). [3]. Перевищення КА більше 30\% та його зменшення нижче -30\% засвідчує виражене переважання (латералізація) моторної функції лівої півкулі (виражена праворукість) та виражене переважання моторної функції правої півкулі (виражена ліворукість), відповідно.

3 огляду на останнє основною метою даної роботи було визначення статевих особливостей сенсомоторної функції з урахуванням моторної асиметрії. Крім того, у даному досліджені нами уточнені [29] та доповнені [24] дані щодо оціночних критеріїв показників сенсомоторної функції, які були отримані раніше з використанням приладу КВР-3 при обстеженні осіб молодого віку чоловічої та жіночої статі. 
3 використанням КВР-3 були обстежені 745 практично здорових осіб молодого віку

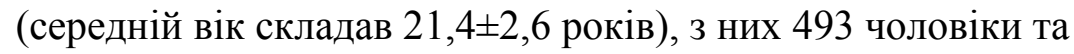

252 жінки.

Таблиця 1. Розподіл обстежених з урахуванням коефіцієнта моторної асиметрії.

\begin{tabular}{|c|c|c|c|c|c|}
\hline \multirow{2}{*}{ Значення КА } & Переважання & \multicolumn{2}{|c|}{$\begin{array}{c}\text { чоловіки } \\
(\mathrm{n}=493)\end{array}$} & \multicolumn{2}{c|}{$\begin{array}{c}\text { жінки } \\
\text { (n=252) }\end{array}$} \\
\cline { 3 - 6 } & & абс. & $\%$ & абс. & $\%$ \\
\hline$<-30 \%$ & Виражено ліворукі & 23 & 4,7 & 10 & 4,0 \\
\hline$-30--10 \%$ & Ліворукі & 90 & 18,3 & 48 & 19,0 \\
\hline$-10-10 \%$ & Амбідекстри & 196 & 39,8 & 77 & 30,0 \\
\hline $10-30 \%$ & Праворукі & 135 & 27,4 & 83 & 32,9 \\
\hline$>30 \%$ & Виражено праворукі & 49 & 9,9 & 34 & 13,5 \\
\hline
\end{tabular}

Як видно з табл. 1 з урахуванням значень КА, які свідчать про активність моторних ділянок кори правої та лівої півкуль головного мозку, а також про переважне управління рухами, розподіл за частотою зустрічності переважних варіантів у чоловіків і жінок молодого віку майже не відрізняється. Певної уваги заслуговує перерозподіл амбідекстрів та праворуких, який у жінок зміщений у бік останніх. Також інформативним $є$ те, що частота виражено ліворуких серед чоловіків та жінок вірогідно не відрізняється та не перевищує 5\% (4,7\% проти 4\%, відповідно). В той же час варіанти ліворукості (свідчать про переважну участь правих відділів моторної кори у реалізації рухів) у поєднанні з вираженою ліворукістю не перевищують $23 \%$ як серед чоловіків, так і серед жінок. Вірогідним є те, що серед жінок варіанти праворукості $\epsilon$ частішими, ніж у чоловіків (46,4\% проти 37,3\%). Доповнює отримані дані також інформація про найбільш часті варіанти серед чоловіків та жінок. Так, серед перших вірогідно переважають варіанти амбідекстрії (39,8\%), в той час як у других в однаковій мірі найчастішими є варіанти праворукості (32,9\%) та амбідекстрії (30\%).

3 урахуванням розподілу за КА були сформовані 10 груп осіб окремо для чоловіків і жінок: 3 вираженою праворукістю - ВПч та ВПЖ, праворукістю - Пч та ПЖ, без переважання (амбідекстрів) - БПч та БПж, ліворукістю - Лч та Лж, вираженою ліворукістю - ВЛч та ВЛЖ, чисельний склад яких представлений у вищезгаданій таблиці.

Для вирішення поставлених у роботі завдань нами досліджувались відмінності пересічних значень показників сенсомоторної функції, що досягалось з використанням 
непараметричних методів статистичного дослідження 3 визначенням критерію вірогідності відмінностей Ман-Уїтні.

Як згадувалось вище показник ТЦР засвідчує провідність нейронних систем, включаючи синапси, що забезпечується низкою нейромедіаторів центральної нервової системи. В першу чергу, мова йде про провідні шляхи підкіркових утворень головного мозку, в яких відбувається перемикання нейронів різних відділів кори, мозочка, ядр екстрапірамідної системи тощо [18].

3 рис. 5 та 6 видно, що вірогідні відмінності показника ТЦР у чоловіків $(\mathrm{p}<0,05)$ групи ВПч у порівнянні з групою Пч відзначаються при виконанні тесту лівою рукою (рис. 5а). При тому, що при виконанні тесту правою рукою вірогідних відмінностей не відзначається (рис. 6а), хоча показник ТЦР у чоловіків групи ВЛч $є$ найменшим серед чоловіків усіх груп, проте не вірогідно (p>0,05).

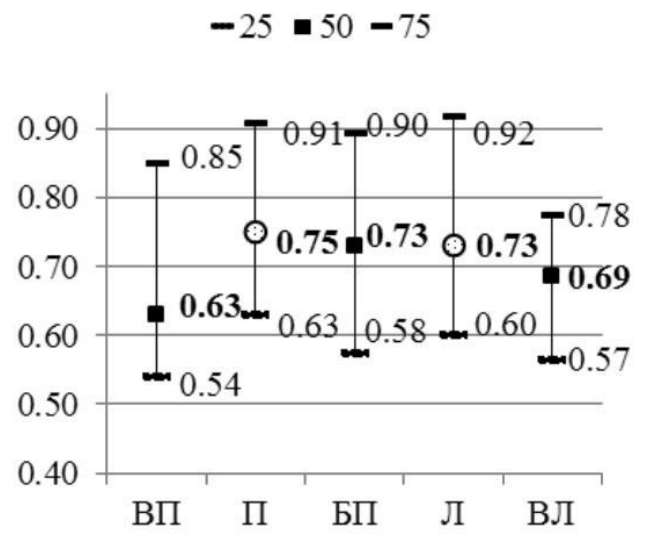

a

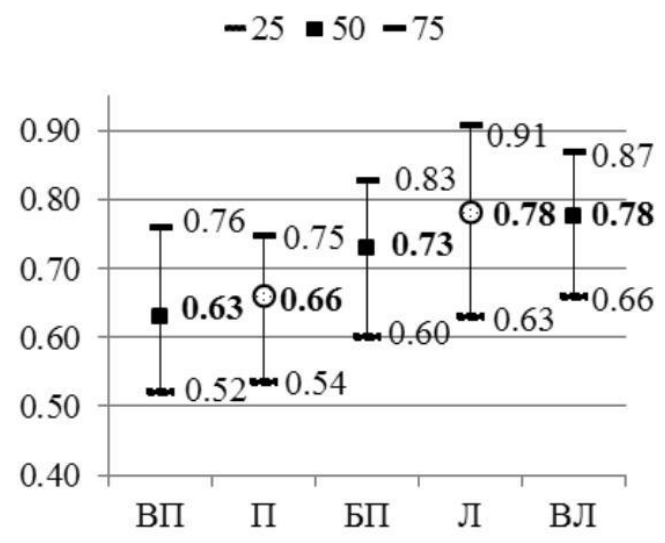

6

Рис. 5. Аналіз (Med, $\mathrm{Q}_{1}, \mathrm{Q}_{3}$ ) даних виміру ТЦР (л) у чоловіків (а) та жінок (б) 3 урахуванням моторної асиметрії: ВП - виражено праворукі, П - праворукі, БП - без переважання (амбідекстри), Л - ліворукі, ВЛ - виражено ліворукі.

В той же час у жінок, показник ТЦР достатньо чітко вірогідно диференціюється як при виконанні тестів лівою, так і правою рукою.

Насамперед, жінки груп Лж та ВЛж відрізняються за ТЦР від жінок груп Пж та ВПж, у яких ТЦР вірогідно менша $(\mathrm{p}<0,01)$ при виконанні рухів лівою рукою (рис. 5б). При цьому відмінності ліворуких та праворуких жінок від жінок-амбідекстрів не достатньо вірогідні. При виконанні тесту правою рукою жінки групи ВЛж вірогідно $(\mathrm{p}<0,05)$ відрізняються за показником ТЦР від жінок груп ВПж та Пж, який у останніх також менший

(рис. 6б). 


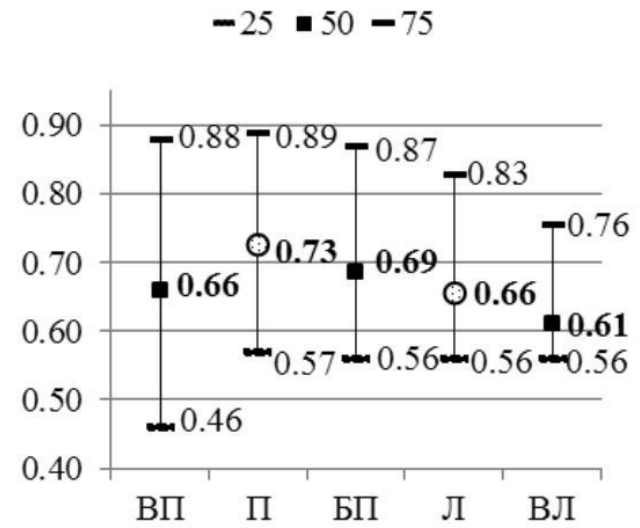

a

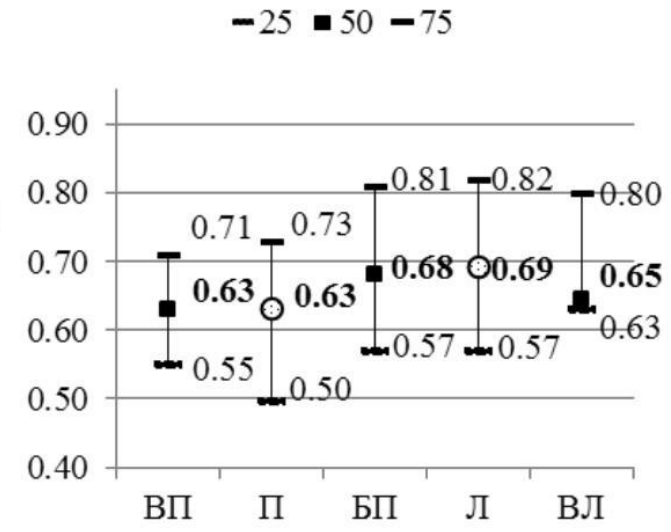

6

Рис. 6. Аналіз (Med, $\mathrm{Q}_{1}, \mathrm{Q}_{3}$ ) даних виміру ТЦР (п) у чоловіків (а) та жінок (б) 3 урахуванням моторної асиметрії: ВП - виражено праворукі, П - праворукі, БП - без переважання (амбідекстри), Л - ліворукі, ВЛ - виражено ліворукі.

Тобто, на підставі аналізу показника ТЦР можна припустити, що серед чоловіків при вираженій праворукості, процеси синаптичного перемикання у підкірці правої півкулі та структурах, що розташовані нижче, є швидшими, ніж при праворукості. Аналогічний перебіг процесів синаптичного перемикання спостерігається у чоловіків при вираженій ліворукості тільки в підкіркових структурах лівої півкулі, проте на рівні тенденції. У виражено праворуких та праворуких жінок можна стверджувати, що провідність по підкіркових структурах $є$ вірогідно швидшою в правій півкулі у порівнянні з виражено ліворукими та ліворукими, а також в лівій півкулі у порівнянні з виражено ліворукими.

Показник ПЦУ, як згадувалося вище, пов'язаний із швидкістю перемикань у префронтальній корі і певним чином визначає адаптивні можливості моторики. Як видно 3 рис. 7 та 8 він суттєво відрізняється у чоловіків та жінок $з$ різними варіантами моторної асиметрії. В першу чергу необхідно звернути увагу на те, що у праворуких та ліворуких чоловіків і жінок дисперсія цього показника при виконанні тесту лівою рукою суттєво менша (рис. 7 а, б). Тобто, процеси перемикання у префронтальній корі правої півкулі головного мозку відбуваються в цілому швидше.

Насамперед, це стосується вірогідних $(\mathrm{p}<0,01)$ відмінностей у групах ВПж (рис. 76 та 8б), а також Пч та БПч (рис. 7а та 8а). 

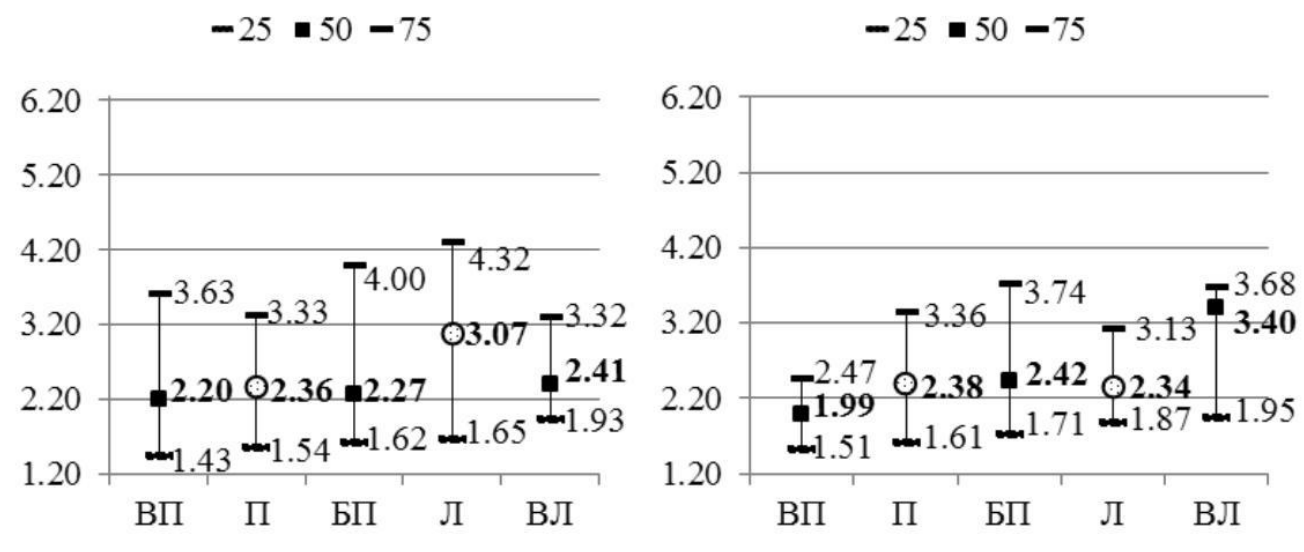

a

6

Рис. 7. Аналіз (Med, $\mathrm{Q}_{1}, \mathrm{Q}_{3}$ ) даних виміру ПЦУ (л) у чоловіків (а) та жінок (б) з урахуванням моторної асиметрії: ВП - виражено праворукі, П - праворукі, БП - без переважання (амбідекстри), Л - ліворукі, ВЛ - виражено ліворукі.

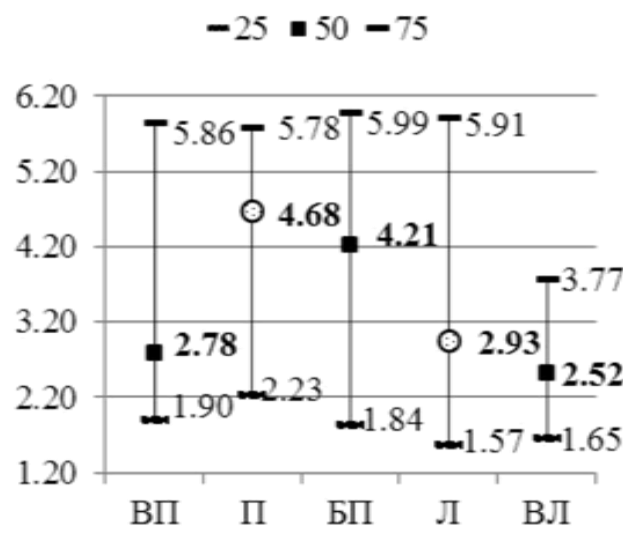

a

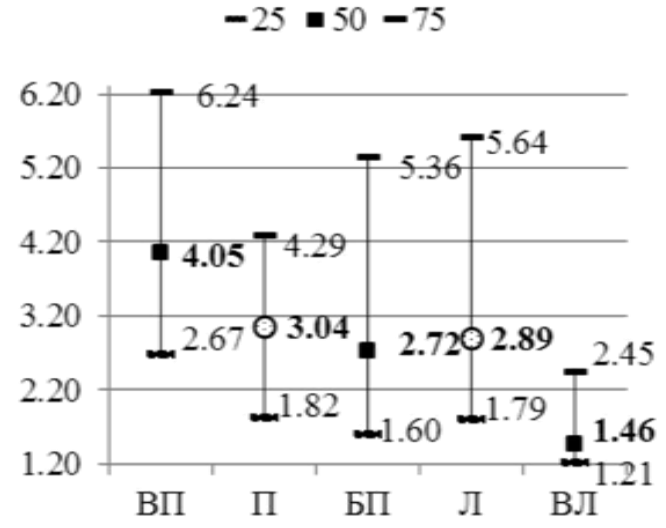

б

Рис. 8. Аналіз (Med, $\mathrm{Q}_{1}, \mathrm{Q}_{3}$ ) даних виміру ПЦУ (п) у чоловіків (а) та жінок (б) з урахуванням моторної асиметрії: ВП - виражено праворукі, П - праворукі, БП - без переважання (амбідекстри), Л - ліворукі, ВЛ - виражено ліворукі.

Єдиним винятком у цьому плані є жінки групи ВЛж, у яких відзначається вірогідне $(\mathrm{p}<0,05)$ пришвидшення процесів перемикання у префронтальній корі лівої півкулі головного мозку (рис. 8 б). Винятковим для цих жінок також є вірогідне $(p<0,05)$ уповільнення процесів перемикання у префронтальній корі правої півкулі у порівнянні з іншими варіантами моторної асиметрії у жінок (рис. 7 б) та групами чоловіків ВЛч $(\mathrm{p}<0,01)$ та Пч $(\mathrm{p}<0,05)$ (рис. 7 a, б). У чоловіків групи ВЛч також спостерігається тенденція до пришвидшення процесів перемикання у префронтальній корі лівої півкулі головного мозку, проте вірогідною $(\mathrm{p}<0,05)$ вона $\epsilon$ тільки у порівнянні з чоловіками груп Пч та БПч (рис. 8 а).

Тобто, за даними аналізу показника ПЦУ можна припустити, що уважність та швидкість перемикання рухових дій у відповідь на зміну подразника пов'язані із моторною асиметрією як у чоловіків, так і у жінок,

проте - по-різному. Як у чоловіків, так і у жінок, процес перемикання відбувається швидше в префронтальних зонах правих півкуль головного мозку. При цьому вірогідно найбільше уповільнення у лівих півкулях головного мозку відзначається у праворуких 
чоловіків, чоловіків-амбідекстрів та виражено праворуких жінок. В той же час вірогідним є уповільнення перемикання в правих півкулях головного мозку у виражено ліворуких жінок. Заслуговує уваги також вірогідне пришвидшення даного процесу у правих відділах префронтальної кори у виражено праворуких жінок та у лівих відділах - у виражено ліворуких жінок.

На рис. 9 та 10 представлені результати аналізу показників КРП. Впершу чергу, слід зазначити більш виражену дисперсію даних показників зі зрушенням у бік збільшення цього показника у чоловіків незалежно від моторної асиметрії при виконанні тесту правою рукою, при тому, що у жінок при всіх варіантах моторної асиметрії, за винятком груп ВПж та ВЛж, цей показник вірогідно не відрізняється ні за дисперсією, ні за медіанними значеннями. У групі ВПж дисперсія показника є вірогідно більшою при виконанні тесту лівою рукою, а у групі ВЛж - правою. При цьому в останній групі жінок значення КРП є більшими, хоча й не вірогідно (p>0,05), ніж у більшості інших груп чоловіків та жінок.

Враховуючи те, що даний показник пов'язаний із здатністю до навчання рухам, то можна припустити, що чоловіки більше схильні до засвоєння рухових дій правою рукою (рис. 9а, 10a). Серед жінок виділяються групи ВПж та ВЛж, які більш схильні до засвоєння рухів лівою (рис. 9 б) та правою рукою (рис. 10 б), відповідно.

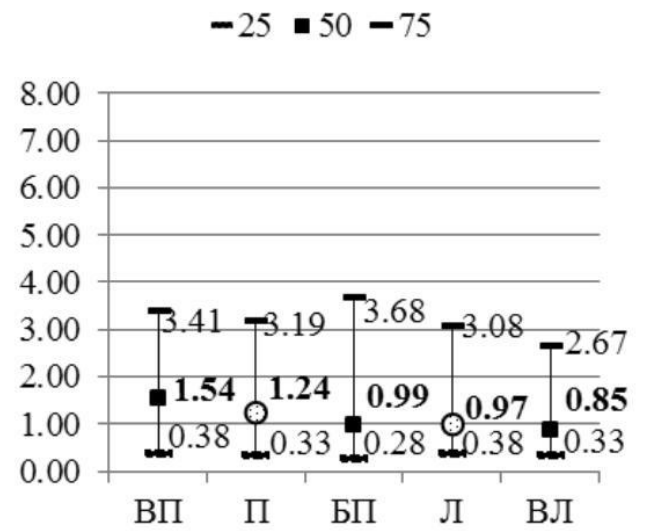

a

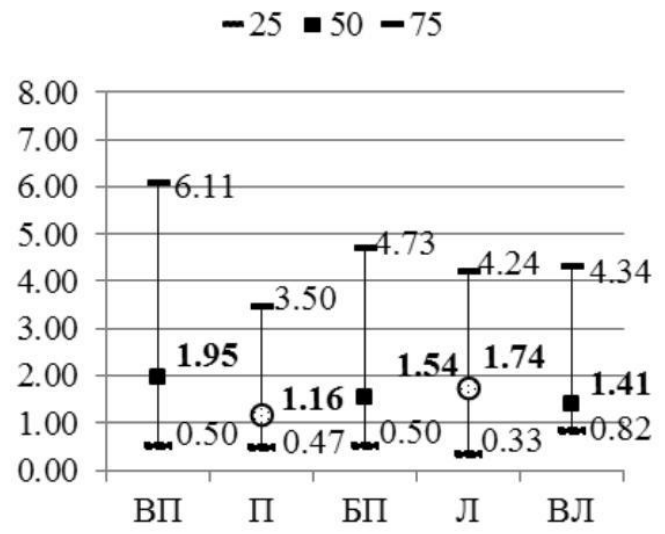

б

Рис. 9. Аналіз (Med, $\mathrm{Q}_{1}, \mathrm{Q}_{3}$ ) даних виміру КРП (л) у чоловіків (а) та жінок (б) 3 урахуванням моторної асиметрії: ВП - виражено праворукі, П - праворукі, БП - без переважання (амбідекстри), Л - ліворукі, ВЛ - виражено ліворукі. 


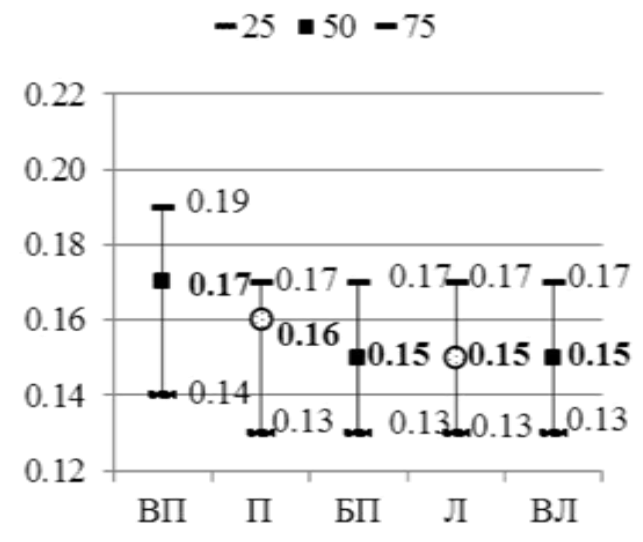

a

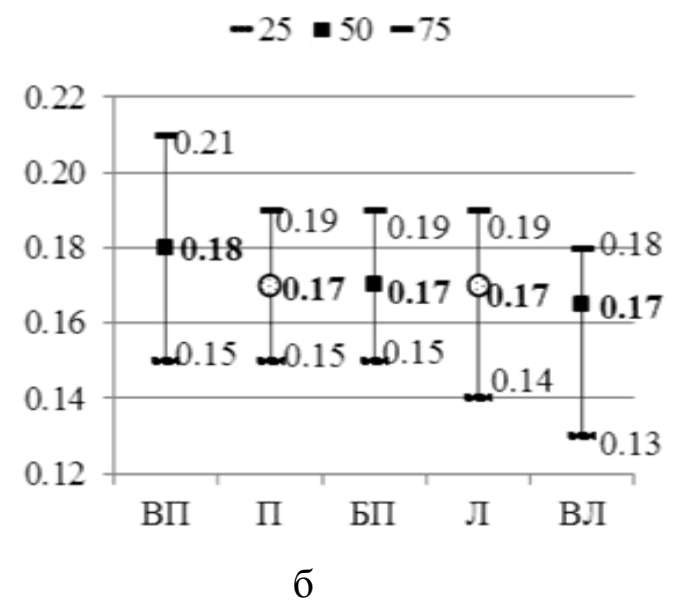

б

Рис. 10. Аналіз (Med, $\mathrm{Q}_{1}, \mathrm{Q}_{3}$ ) даних виміру КРП (п) у чоловіків (а) та жінок (б) 3 урахуванням моторної асиметрії: ВП - виражено праворукі, П - праворукі, БП - без переважання (амбідекстри), Л - ліворукі, ВЛ - виражено ліворукі.

Достатньо інформативним виявився аналіз результатів дослідження латентних періодів простої рухової реакції на світловий (рис. 11 та 12) та звуковий (рис. 13 та 14) подразники. В першу чергу слід звернути увагу на те, що при більшості варіантів моторної асиметрії відзначаються вірогідні відмінності простої рухової реакції на світловий подразник (ЧРС) у чоловіків та жінок, які в останніх за тривалістю латентного періоду дещо більші $(\mathrm{p}<0,05)$. Винятком у цьому плані $є$ відсутність відмінностей показника ЧРС між групами ВПч та ВПж при виконанні тестів лівою рукою (рис. 11 а, б), між групами Пч та Пж, а також групами Лч та Лж при виконанні тестів правою рукою (рис. 12 a, б). В той же час за реакцією на звуковий подразник (ЧРЗ) групи чоловіків та жінок (рис. 13,14$)$ взагалі не відрізняються за винятком груп Лж при виконанні тесту лівою рукою (рис. 13 б) та ВЛж при виконанні тесту правою рукою (рис. 14 б).

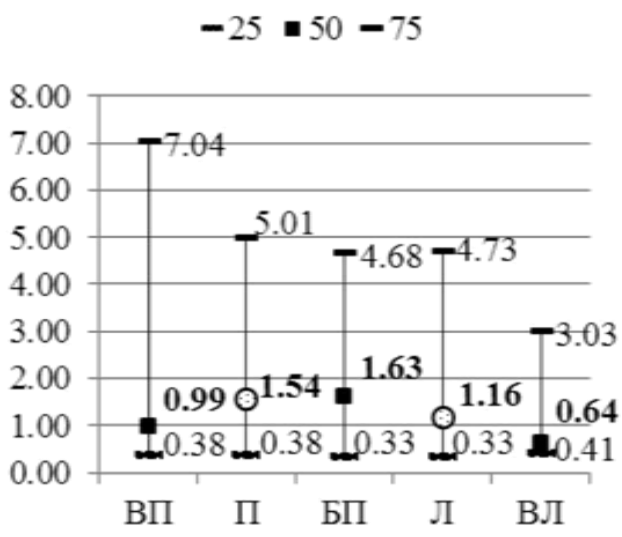

a

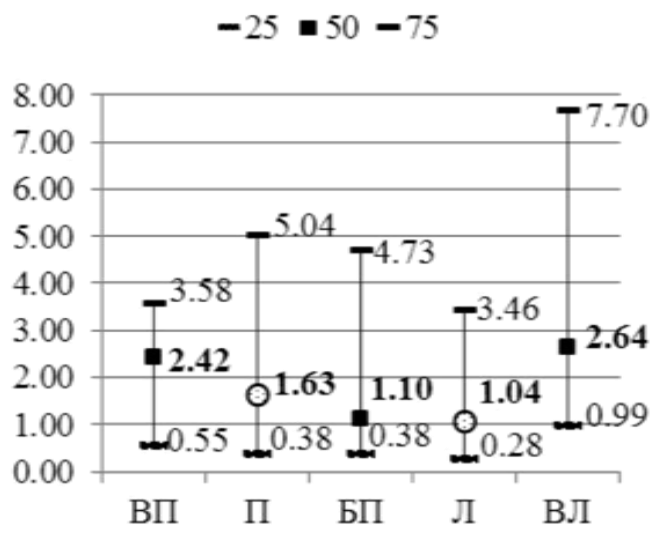

6

Рис. 11. Аналіз (Med, $\mathrm{Q}_{1}, \mathrm{Q}_{3}$ ) даних виміру ЧРС (л) у чоловіків (а) та жінок (б) 3 урахуванням моторної асиметрії: ВП - виражено праворукі, П - праворукі, БП - без переважання (амбідекстри), Л - ліворукі, ВЛ - виражено ліворукі. 
Порівнюючи групи моторної асиметрії у чоловіків за показником ЧРС слід зазначити, що тільки у групі ВПч відзначається вірогідне $(\mathrm{p}<0,05)$ уповільнення реакції на світловий подразник при виконанні тесту лівою рукою (рис. 11a). Вірогідне уповільнення відзначається й у групі чоловіків Пч при виконанні тесту правою рукою, але тільки у порівнянні з результатами тестів цієї групи чоловіків лівою рукою (рис. 11а та 12a).
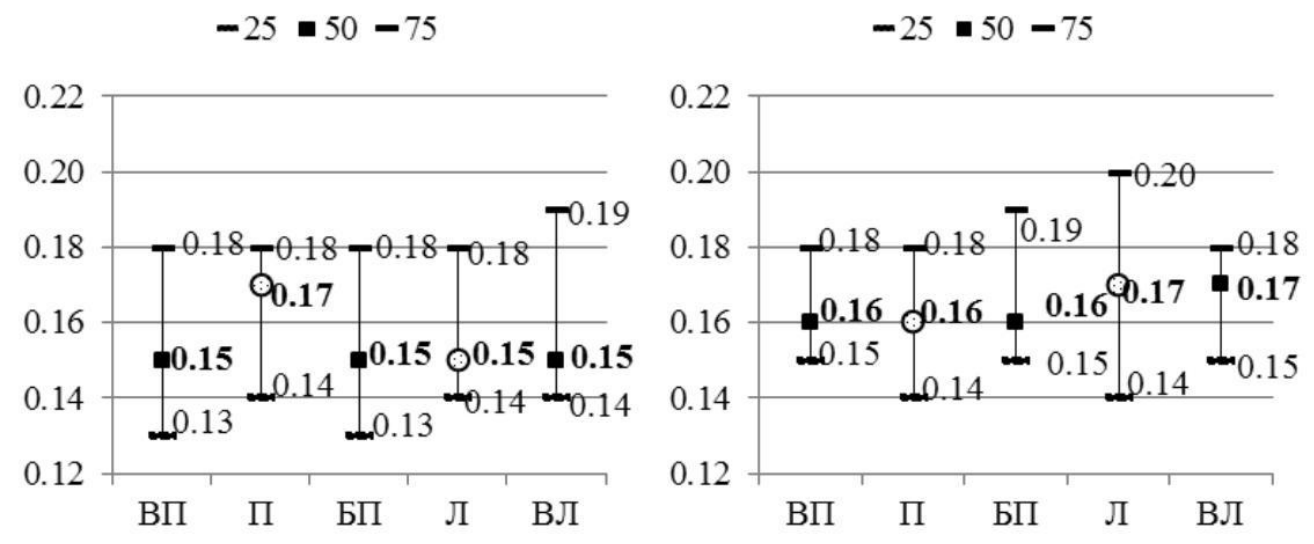

a

Рис. 12. Аналіз (Med, $\mathrm{Q}_{1}, \mathrm{Q}_{3}$ ) даних виміру ЧРС (п) у чоловіків (а) та жінок (б) 3 урахуванням моторної асиметрії: ВП - виражено праворукі, П - праворукі, БП - без переважання (амбідекстри), Л - ліворукі, ВЛ - виражено ліворукі.

Аналізуючи результати тестування простої рухової реакції на світловий подразник у жінок з різними варіантами моторної асиметрії, слід звернути увагу на те, що тільки жінки групи ВЛж мають вірогідно менший латентний період реакції на світловий подразник $(\mathrm{p}<0,05)$ при виконанні тесту лівою рукою та й то тільки у порівнянні з групою ВПЖ (рис. 11 б). Тільки $\quad$ у $\quad$ групі $Л_{Ж} \quad$ (рис. 13 б) відзначається вірогідне $\quad(p<0,05)$ пришвидшення реакції на одразник у порівнянні 3 іншими варіантами моторної асиметрії жінок при виконанні тесту лівою рукою. В той же час (рис. 14 б) у групі жінок ВЛж відзначається вірогідне збільшення латентного періоду реакції при виконанні тесту правою рукою у порівнянні з іншими групами за винятком групи ВПж. 

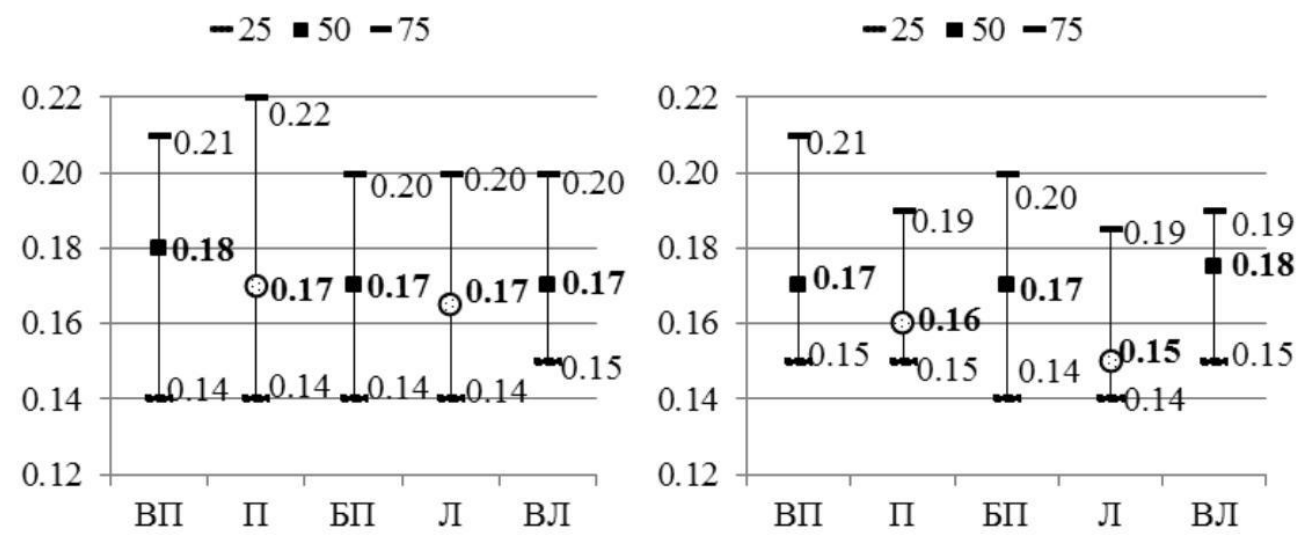

a

6

Рис. 13. Аналіз (Med, $\mathrm{Q}_{1}, \mathrm{Q}_{3}$ ) даних виміру ЧРЗ (л) у чоловіків (а) та жінок (б) 3 урахуванням моторної асиметрії: ВП - виражено праворукі, П - праворукі, БП - без переважання (амбідекстри), Л - ліворукі, ВЛ - виражено ліворукі
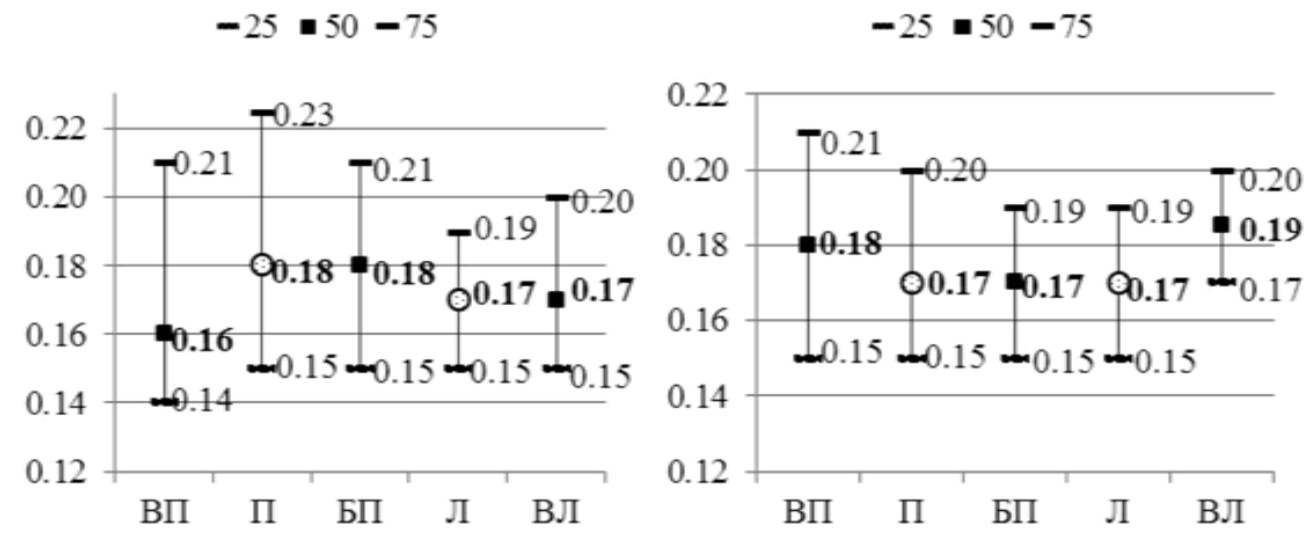

Рис. 14. Аналіз (Med, $\mathrm{Q}_{1}, \mathrm{Q}_{3}$ ) даних виміру ЧРЗ (п) у чоловіків (а) та жінок (б) 3 урахуванням моторної асиметрії: ВП - виражено праворукі, П - праворукі, БП - без переважання (амбідекстри), Л - ліворукі, ВЛ - виражено ліворукі.

Моторні здібності, пов'язані із координованістю рухів можливо дослідити з урахуванням дослідження влучності та плавності рухів. Якщо влучність являє собою кінцевий результат виконання рухової дії, спрямованої на досягнення певної установки, то плавність рухів характеризує погодженість процесу реалізації рухової дії м'язами антагоністами та синергістами, яка контролюється на всіх рівнях організації рухової дії. На рис. 15-18 представлений аналіз показників помилок корекції рухів флексорами (ПКФ) та екстензорами (ПКЕ), визначення яких базується на розрахунку величини «промахів» курсора в точках зміни напрямку руху (рис. 2). Ці показники прямо свідчать про влучність потрапляння курсору на світлодіод, що світиться, при виконанні першого тесту. Як видно з рис. 15-18, існують чіткі поліноміальні залежності між право-, ліво- рукістю, виконуваним тестом та величиною промахів (влучністю), що $є$ підставою для окремого аналізу. Наразі тільки констатуємо, що при виконанні тесту 
протилежною переважній рукою, влучність вірогідно зменшується, що відображається у показниках ПКЕ та ПКФ. У даній статті розглянемо відмінності абсолютних значень у чоловіків та жінок з урахуванням моторної асиметрії.

$$
-25 \cdot 50-75
$$

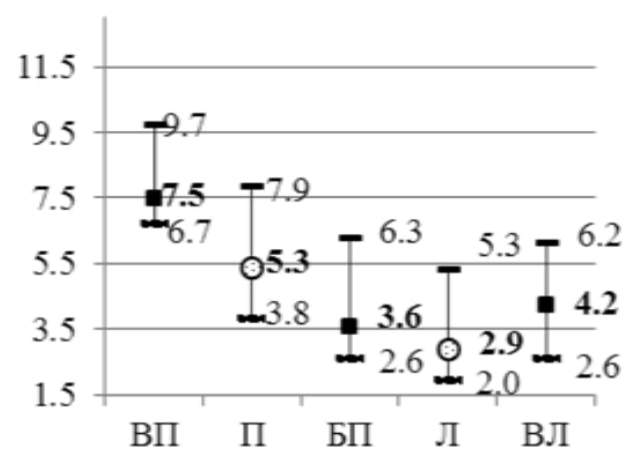

a

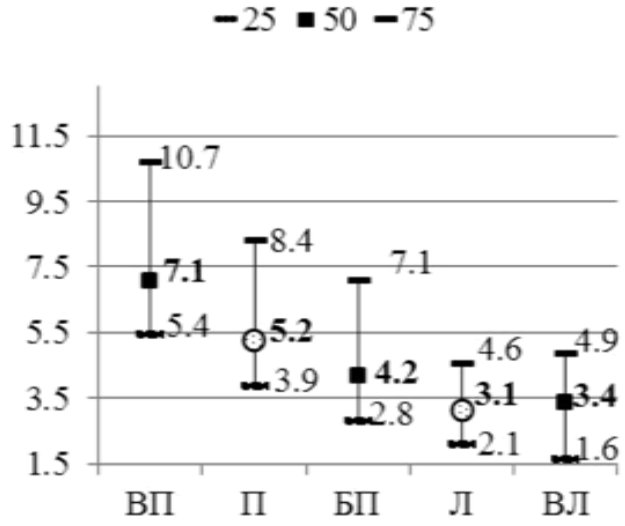

6

Рис. 15. Аналіз (Med, $\mathrm{Q}_{1}, \mathrm{Q}_{3}$ ) даних виміру ПКФ (л) у чоловіків (а) та жінок (б) 3 урахуванням моторної асиметрії: ВП - виражено праворукі, П - праворукі, БП - без переважання (амбідекстри), Л - ліворукі, ВЛ - виражено ліворукі.
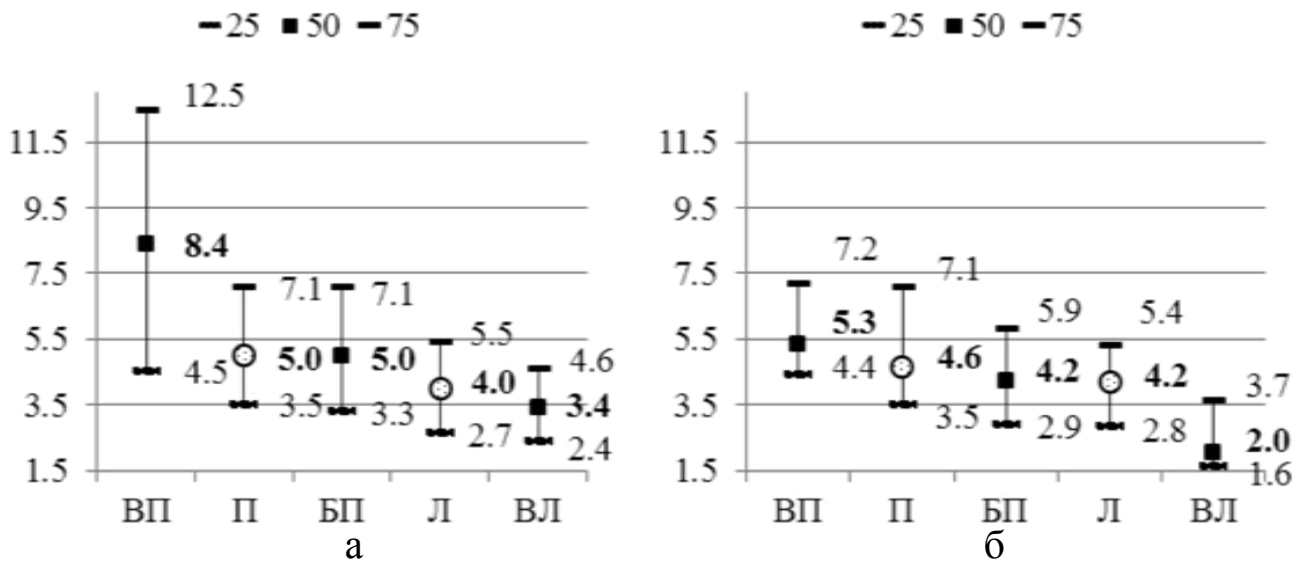

Рис. 16. Аналіз (Med, $\mathrm{Q}_{1}, \mathrm{Q}_{3}$ ) даних виміру ПКФ (п) у чоловіків (а) та жінок (б) 3 урахуванням моторної асиметрії: ВП - виражено праворукі, П - праворукі, БП - без переважання (амбідекстри), Л - ліворукі, ВЛ - виражено ліворукі. 
Показниками, що заслуговують в означеному аспекті на увагу, є показники ПКФ при виконанні тесту лівою рукою у групі жінок групи ВЛж, який вірогідно $(\mathrm{p}<0,05)$ менший, ніж у групі чоловіків ВЛч, та у групі жінок ВПЖ, які також вірогідно $(\mathrm{p}<0,05)$ менші, ніж у групі чоловіків ВПч. Останнє свідчить про те, що влучність рухів лівою рукою у жінок є кращою, ніж у чоловіків.

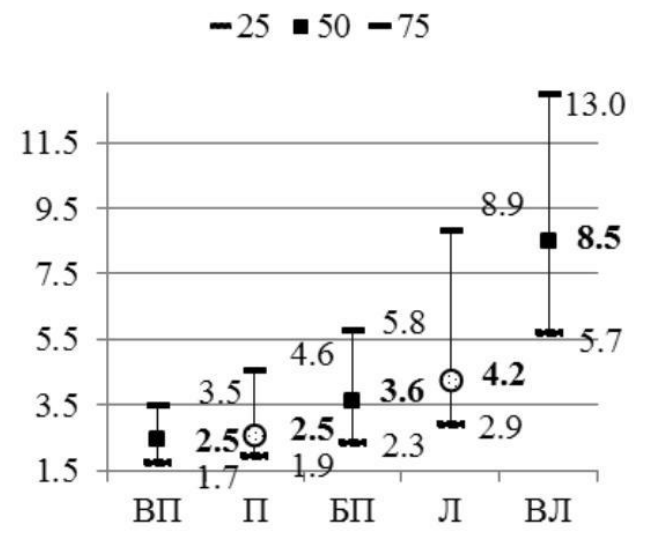

a

$$
-25 \cdot 50-75
$$

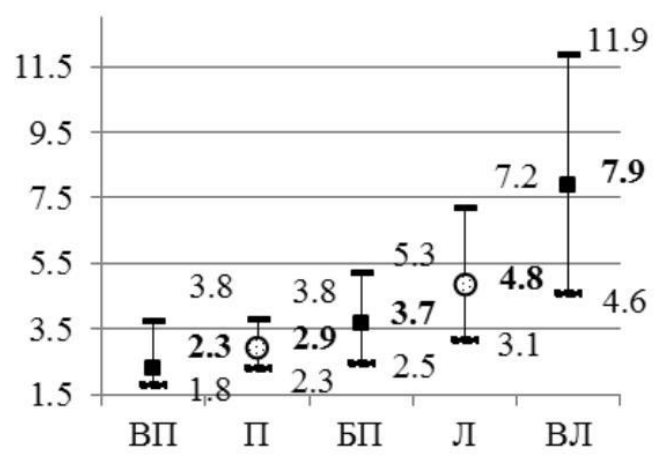

6

Рис. 17. Аналіз (Med, $\mathrm{Q}_{1}, \mathrm{Q}_{3}$ ) даних виміру ПКЕ (л) у чоловіків (а) та жінок (б) з урахуванням моторної асиметрії: ВП - виражено праворукі, П - праворукі, БП - без переважання (амбідекстри), Л - ліворукі, ВЛ - виражено ліворукі.

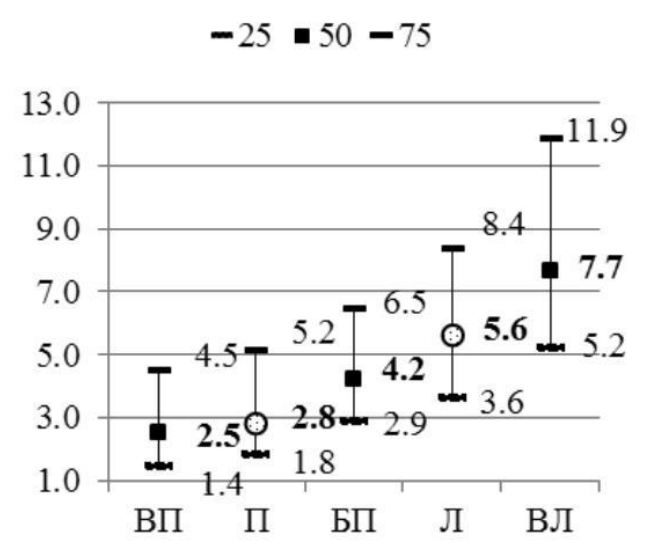

a

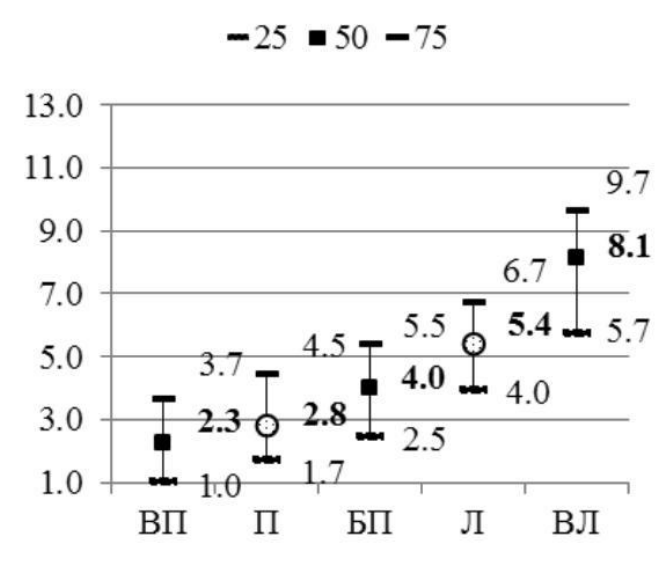

6

Рис. 18. Аналіз (Med, $\mathrm{Q}_{1}, \mathrm{Q}_{3}$ ) даних виміру ПКЕ (п) у чоловіків (а) та жінок (б) з урахуванням моторної асиметрії: ВП - виражено праворукі, П - праворукі, БП - без переважання (амбідекстри), Л - ліворукі, ВЛ - виражено ліворукі.

Згідно аналізу інших показників вірогідних відмінностей між жінками та чоловіками з урахуванням моторної асиметрії не відзначалось. Проте, напрошується висновки, пов'язаніз необхідністюврахування моторної асиметрії при оцінці влучності, а також можливості прогнозування та контролю розвитку влучності, як якості, особливо у спортсменів видів спорту, діяльність яких пов'язана із проявом даної здібності. Проте, останнє вимагає подальшого уточнення. 
На рис. 19, 20 представлений аналіз показників ПР, з якого випливає, що ПР як у чоловіків, так і у жінок є кращою при виконанні рухів лівою рукою в цілому не залежно від моторної асиметрії (рис. 19 а, б). Винятком є ПР у групах ВЛч та ВЛж. У першій відзначається збільшення дисперсії ПР, а у другій - зменшення. Інша ситуація складається при виконанні рухів правою рукою (рис. 20 а, б).

Так, ПР у групі чоловіків ВПч при виконанні тесту правою рукою (рис. 20 а) $\epsilon$ вірогідно $(p<0,05)$ нижчою від ПР цієї ж групи чоловіків при виконанні тесту лівою рукою. Такий же варіант $(\mathrm{p}<0,05)$ спостерігається в групі чоловіків Лч. У жінок, не дивлячись на більшу дисперсію показників, відмінності ПР при виконанні рухових тестів правою та лівою рукою не вірогідні.
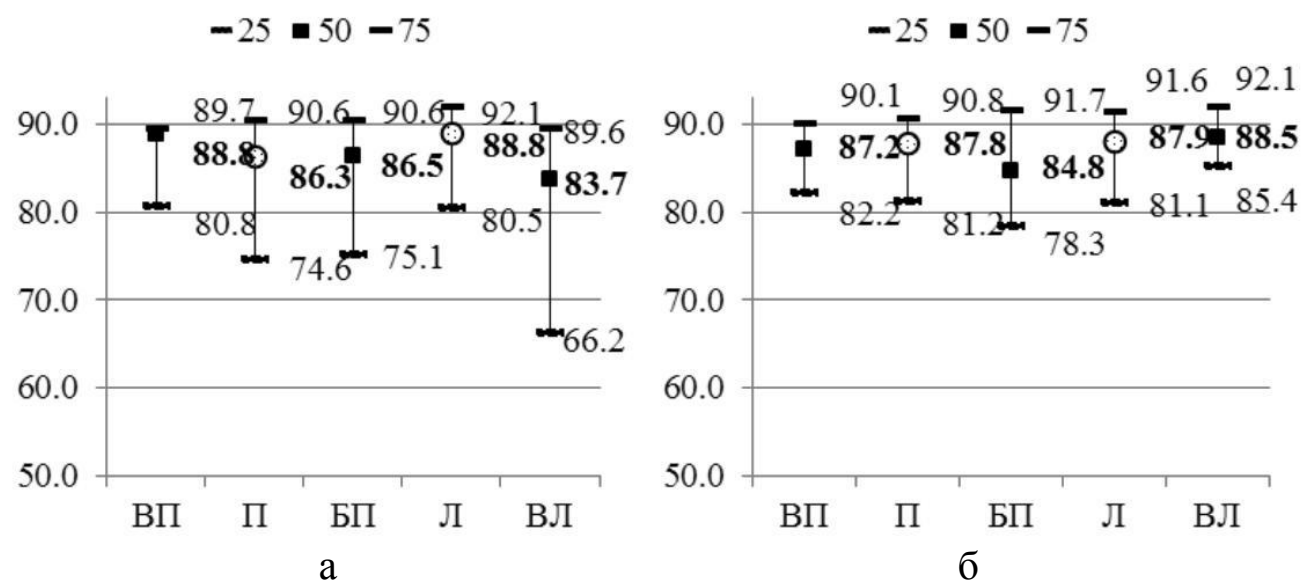

Рис. 19. Аналіз (Med, Q1, Q3) даних виміру ПР (л) у чоловіків (а) та жінок (б) 3 урахуванням моторної асиметрії: ВП - виражено праворукі, П - праворукі, БП - без переважання (амбідекстри), Л - ліворукі, ВЛ - виражено ліворук.

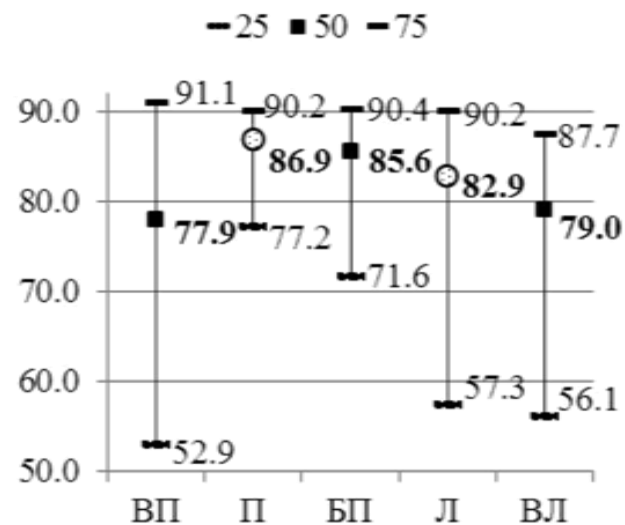

$\mathrm{a}$

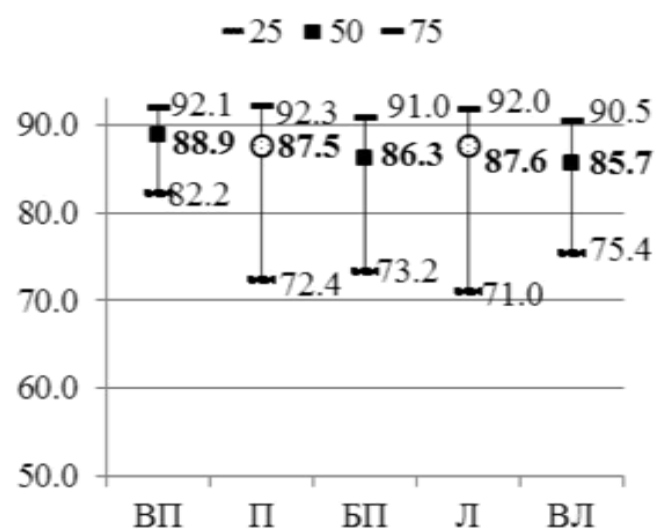

6

Рис. 20. Аналіз (Med, $\mathrm{Q}_{1}, \mathrm{Q}_{3}$ ) даних виміру ПР (п) у чоловіків (а) та жінок (б) 3 урахуванням моторної асиметрії: ВП - виражена праворукість, П - праворукість, БП без переважання, Л - ліворукість, ВЛ - виражена ліворукість. 


\section{Обговорення результатів дослідження}

Головною метою даного дослідження було виявлення статевих відмінностей сенсомоторної функції з урахуванням моторної асиметрії, тому в обговоренні результатів ми акцентуємо увагу на цих відмінностях. На початку обговорення слід зазначити, що порівняння параметрів сенсомоторної функції у чоловіків та жінок амбідекстрів дозволило виявити вірогідні відмінності тільки за показниками тривалості латентного періоду простої рухової реакції на світловий подразник, який у жінок був вірогідно більшим при рухах правою та лівою руками. 3 інших показників заслуговує на увагу тільки певна тенденція до збільшення тривалості ПЦУ у префронтальних зонах кори лівої півкулі головного мозку у чоловіків-амбідекстрів.

Аналізуючи результати порівняння груп виражено праворуких чоловіків та жінок (ВПч та ВПж), відзначимо, що вірогідні відмінності в показниках сенсомоторики останніх відзначаються при тестах, які виконуються правою рукою. Причому відбувається це на всіх рівнях реалізації сеномоторної функції - центральному (за показником ПЦУ), синаптичному (за показником ПР) та медулярному (за показником ЧРС).

Показано, що у праворуких жінок на відміну від чоловіків процеси обробки інформації у префронтальній зоні кори лівих півкуль головного мозку відбуваються повільніше, причому таке уповільнення є вірогідним у порівнянні з жінками-амбідекстрами, виражено ліворукими жінками та швидкістю перемикання у префронтальній зоні кори правої півкулі головного мозку, що дозволяє охарактеризувати даний показник, як специфічний для праворуких жінок. До речі, підкреслюють останнє дзеркальні зміни при виконанні тестів лівою рукою та особливості центральних механізмів у виражено ліворуких жінок (ВЛЖ), у яких показник ПЦУ є найменшим у порівнянні не тільки з виражено ліворукими чоловіками, але й $з$ жінками-амбідекстрами, з виражено ліворукими жінками при виконанні тестів лівою рукою, а також з виражено праворукими жінками, як вказувалось вище. Тобто, у виражено ліворуких жінок процеси обробки інформації у префронтальній зоні кори лівої півкулі головного мозку є досить швидкими.

Вірогідні відмінності у виражено ліворуких жінок (ВЛж) у порівнянні з виражено ліворукими чоловіками (ВЛч) відзначаються за більшістю й інших показників сенсомоторики: ТЦР (правою та лівою рукою), який засвідчує більш тривалий період інтеграції підкіркових процесів у жінок, КРП (правою та лівою рукою), який засвідчує більшу схильність до засвоєння рухових дій, ЧРС (правою та лівою рукою), що характеризує більш повільний перебіг процесів на медулярному 
рівні реалізації рухів та ПР (правою та лівою рукою), що може свідчити про більшу врівноваженість виражено ліворуких жінок, у порівнянні з виражено ліворукими чоловіками. При цьому за останнім показником відзначається достатньо чітка тенденція у порівнянні не тільки з виражено ліворукими чоловіками, а й з жінками 3 іншими варіантами моторної асиметрії. Крім того, виражено праворукі жінки (ВПЖ) у порівнянні з виражено праворукими чоловіками (ВПч) також вірогідно відрізняються при виконанні тесту правою рукою, що засвідчує збалансованість процесів збудження та гальмування у підкоркових структурах лівої півкулі головного мозку, як у виражено ліворуких, так і у виражено праворуких жінок.

Повертаючись до виражено праворуких чоловіків (ВПч) необхідно зазначити, що окрім вище згаданих відмінностей при виконанні тестів правою рукою, відзначаються певні тенденції у порівнянні з виражено праворукими жінками (ВПж), які стосуються уповільнення процесів перемикання в правих відділах префронтальної кори головного мозку, зменшення КРП, яка засвідчує гіршу схильність до засвоєння рухів, а також вірогідне зменшення плавності рухів (ПР), яка характеризує незбалансованість процесів збудження та гальмування у підкіркових структурах лівої півкулі, причому й у порівнянні з правою півкулею.

\section{Висновок.}

Дослідження статевих особливостей сенсомоторної функції осіб молодого віку 3 урахуванням моторної асиметрії дозволило встановити, що найбільш вірогідними $(\mathrm{p}<0,05)$ визначались відмінності у виражено ліворуких жінок, які стосувались центральних (за показником ПЦУ), підкоркових (за показником ТЦР) та медулярних (за показником ЧРС) механізмів організації рухів. Серед результатів дослідження вагомими виявилися дані, які свідчать про поліноміальну залежність між показниками влучності правою та лівою рукою з урахуванням моторної асиметрії, як у чоловіків, так і у жінок.

В цілому більшість отриманих даних має сприяти розумінню механізмів функціональної міжпівкульної асиметрії у чоловіків та жінок. Низка даних вимагає подальшого опрацювання та доповнення даними дослідження функціонального стану інших систем. 


\section{References}

1. Arceneaux JM, Hill SK, Chamberlin CM, Dean RS (1997) Developmental and sex differences in sensory and motor functioning. Int. J. Neurosci. 89(3-4):253-63. http://dx.doi.org/10.3109/00207459708988478

2. Bernstein NA (1967) The coordination and regulation of movement. Oxford, UK: Pergamon.

3. Bezrukih M.M., Kiselev M.F., Komarov G.D., Kozlov A.P., Kurneshova L.E., Landa S.B., Noskin L.A., Noskin V.A., Pivovarov V.V. (2000) Age-related features of the organization of motor activity in 6- to 16-year-old children. Human Physiology 6 (337-344) http://dx.doi.org/10.1007/BF02760196

4. Boyko EI. (1964) Vremya reaktsii cheloveka [Human Reaction Time]. Moscow. [in Russian]

5. Bragina NN, Dobrokhotova TA (1988) Funktsionalnyie asimmetrii cheloveka [The functional asymmetry of the person]. Moscow, Medicine [in Russian]

6. Bruno N, Battaglini PP. (2008) Integrating perception and action through cognitive neuropsychology (broadly conceived). Cogn Neuropsychol. 25: 879-90. http://dx.doi.org/10.1080/02643290802519591

7. Craig AD. (2005) Forebrain emotional asymmetry: a neuroanatomical basis? Trends in Cognitive Sciences. 9(12): 566-71. http://dx.doi.org/10.1016/j.tics.2005.10.005

8. Gamble A.L., Rapee R.M. (2009). The Time-Course of Attentional Bias in Anxious Children and Adolescents. J. Anxiety Disord. 23 (7): 841-7. DOI: 10.1016/j.janxdis.2009.04.001.

9. Everts R, Lidzba K, Wilke M, Kiefer C, Mordasini M, Schroth G, Perrig W, Steinlin M. (2009). Strengthening of laterality of verbal and visuospatial functions during childhood and adolescence.Hum. Brain Mapp. 30 (2): 473-483. doi: 10.1002/hbm.20523.

10. Fokin VF (2007) Dinamicheskaya funktsional'naya asimmetriya kak otrazhenie funktsional'nykh sostoyaniy [Dynamic functional asymmetry as a reflection of the functional states]. J. Asymmetry. 1(1):4-9. [in Russian]

11. Fokin VF, Ponomareva NV (2003) Energeticheskaya fiziologiya mozga [Energy physiology of the brain]. Antidor. [in Russian]

12. Il'in E.P. (2003) Psikhomotornaya organizatsiya cheloveka [Psychomotor Organization of Humans]. St. Petersburg.

13. Kavalerskiy GM, Ternovoy KS, Bogachev VY, Romanchuk AP, Nikushkina NE, Lebedeva MA. (2012) Metodika ocenki funkcional"nogo sostojanija psihomotornoj reguljacii u bol"nyh so spinnomozgovoj travmoj [Methods assess the functional state of psychomotor regulation in patients with SCI] [Regenerative Medicine Journal]. 3:12-15. DOI: 10.5281/zenodo.18235

14. Kerick SE, Douglass LW, Hatfield BD. (2004) Cerebral cortical adaptations associated with visuomotor practice. Med Sci Sports Exerc. 36:118-29. DOI: 10.1249/01.MSS.0000106176.31784.D4

15. Klasik A, Janas-Kozik M, Krupka-Matuszczyk I, Augustyniak E (2006) [Cognitive functions, their development and modern diagnostic methods]. Przegl Lek. 63 Suppl 1:29-34. [in Polish] PMID: 17471820

16. Levy J. A (1976) Review of Evidence for a Genetic Component in the Determination of Handedness. Behavior. Genetics. 6 (4):429-53

17. Machado S, Cunha M, Portella CE, Silva JG, Velasques B, Bastos VH, Basile L., Cagya M, Piedade RA, Ribeiroa P. (2008) Participación de la corteza parietooccipital en el proceso de integración sensoriomotora: studio electroencefalográfico. Rev Neurol. 47: 146-9.

18. Machado S, Cunha M, Velasques B, Minc D, Teixeira S, Domingues CA, Silva JG, Bastos VH, Budde H, Cagy M, Basile L, Piedade R, Ribeiro P (2010) Sensorimotor integration: basic concepts, abnormalities related to movement disorders and sensorimotor training-induced cortical reorganization. Rev Neurol. 51(7):427-436. 
19. Martinez-Sanchis S (2015) The role of the prefrontal cortex in the sensory problems of children with autism spectrum disorder and its involvement in social aspects. Rev Neurol. 60(S01):19-24. PMID: 25726818

20. McManus Ch. (2002) Right hand, left hand. London: Clays Ltd, St. Ives pic. 21. Monfils MH, Plautz EJ, Kleim JA. (2005) In search of the motor engram: motor map plasticity as a mechanism for encoding motor experience. Neuroscientist. 11:471-83. doi: $10.1177 / 1073858405278015$

21. Nehoroshkova AN, Gribanov AV. (2011) Osobennosti zritel'no-motornykh reaktsiy detey 811 let s vysokim urovnem trevozhnosti [Features of Visual-Motor Reactions of Children Aged 8-11 Years with High Anxiety]. Ekologiya cheloveka, 5: 43-8.

22. Nikandrov V.V. (2004) Psikhomotorika [Psychomotor Response]. St. Petersburg.

23. Noskin L.A., Krivosheev V.F., Kuchma V.R., Rumyantsev A.G., Noskin V.A., Komarov G.D., Karganov M.Yu. (2005). Pedagogicheskaya sanologiya [Pedagogical sanology]. Moskow, MIOE. [in Russian]

24. Oppenheimer SM, Gelb A, Girvin JP, Hachinski VC (1992) Cardiovascular effects of human insular cortex stimulation. Neurology. 42: 1727-32. doi: http://dx.doi.org/10.1212/WNL.42.9.1727

25. Pankova, NB, Kurneshova, LE, Karganov, MYu. (2015) Changes in the dynamics of latent periods of simple sensorimotor responses throughout the academic year in Moscow schoolchildren over 10 years. Int. J. Educ. Pol. Res. Rev. Vol.2 (2), pp. 17-24 http://dx.doi.org/10.15739/IJEPRR.007;

26. Pivovarov V. V. (2006) The computerized motion meter. Biomedical Engineering. 40 (2): 7477 DOI:10.1007/s10527-006-0046-2

27. Polysystemic approach to school, sport and environment medicine (2013). Foster City, USA: OMICS Group eBooks. http://dx.doi.org/10.4172/978-1-63278-000-3-001

28. Romanchuk AP (2007) K voprosu tipirovaniya sensomotornyih reaktsiy u sportsmenov [The question sensorimotor reactions typing in athletes]. Vestnik sportivnoy nauki. 2:38-42. [in Russian] DOI:10.5281/zenodo.16300 30. Quatman-Yates CC, Quatman CE, Meszaros AJ, Paterno MV, Hewett TE (2012) A systematic review of sensorimotor function during adolescence: a developmental stage of increased motor awkwardness? Br. J. Sports Med. 46(9):649-55. http://dx.doi.org/10.1136/bjsm.2010.079616

29. Samuel AD, Sengupta $P$ (2005) Sensorimotor integration: locating locomotion in neural circuits. Curr Biol. 15(9):R341-R343 http://dx.doi.org/10.1016/j.cub.2005.04.021

30. Schalow G. (2010) Scientific basis for learning transfer from movements to urinary bladder functions for bladder repair in human patients with CNS injury Electromyogr. Clin. Neurophysiol. 50 (7-8): 339-95. PMID: 21284372

31. Sergienko E.A. (2002) Sovremennoe issledovanie kognitivnykh protsessov [Contemporary State of Researches on Cognitive Processes]. Psikhologicheskiy zhurnal. 23( 2): 19-35.

32. Takarae Y., Luna B., Minshew N.J., Sweeney J.A. (2008) Patterns of Visual Sensory and Sensorimotor Abnormalities in Autism Vary in Relation to History of Early Language Delay. J. Int. Neuropsychol. Soc. 14 (6): 980-989. doi: 10.1017/S1355617708081277.

33. Willcutt EG, Pennington BF, Duncan L, Smith SD, Keenan JM, Wadsworth S, Defries JC, Olson RK (2010) Understanding the complex etiologies of developmental disorders: behavioral and molecular genetic approaches. J. Dev Behav Pediatr 31(7):533-44 http://dx.doi.org/10.1097/DBP.0b013e3181ef42a1

34. Wolpert DM, Flanagan JR. (2001) Motor prediction. Curr Biol. 11:729-32. DOI: http://dx.doi.org/10.1016/S0960-9822(01)00432-8 